\title{
SURVEY OF RECENTLY REPORTED CASES in Real Property LaW
}

\author{
BRIAN C. CRIST* \\ MICHAEL R. TIRMAN** \\ HALEY SOSHNICK $^{* * *}$
}

\section{INTRODUCTION}

This Article examines the reported decisions during the survey period ${ }^{1}$ of the Indiana Supreme Court (the "Supreme Court"), Court of Appeals of Indiana (the "Court of Appeals"), and the Indiana Tax Court (the "Tax Court") concerning real property issues.

\section{ADVERSE POSSESSION AND PRESCRIPTIVE EASEMENTS}

\section{A. Hardin v. McClintic}

In Hardin v. McClintic, ${ }^{2}$ the Court of Appeals held that it was a consistent ruling by the trial court to grant both an adverse possession claim and a prescriptive easement to a party for the same driveway because, while the adverse possession grant pertained to only a portion of the driveway, the prescriptive easement pertained to the remainder of the driveway, as opposed to both pertaining to the entire driveway. ${ }^{3}$ The Hardins (the "Landowners") and McClintic (the "Claimant") both own property adjacent to one another. ${ }^{4}$ Claimant began living on her property in 1995, and Landowners acquired title to their property in 2007.5 A gravel driveway (the "Driveway") lies between the two properties. ${ }^{6}$ Claimant, and her predecessors in title, had used the Driveway continuously for ingress and egress and contributed to its maintenance since

* Brian C. Crist is a partner in Ice Miller LLP's real estate section. He received his B.A. in History and Economics from the University of Missouri in 1994 and his J.D. from Vanderbilt University in 1997.

** Michael R. Tirman is an associate attorney in Ice Miller LLP's real estate section. He received his B.A. in Music with a second major in Finance from Butler University in 2012 and his J.D. from Northwestern University Pritzker School of Law in 2015.

*** Haley Soshnick is an associate in Ice Miller LLP's real estate section. She received her B.A. in Political Science and French from the University of Michigan in 2015 and her J.D. from Northwestern University Pritzker School of Law in 2018.

The authors would like to thank their colleagues Katie Marschke and Annie Xie and Ice Miller 2019 Summer Clerks Kelly Beyrer, Kole Brinegar, Brian Cavanaugh, Sloan Crawford, Nicola Deans, Ida Hyvarinen, Libby Moyer, and Arqeil Shaw for their contributions to this Article.

1. The survey period runs from July 2018 through June 2019.

2. Hardin v. McClintic, 125 N.E.3d 643 (Ind. Ct. App. 2019).

3. Id. at 645-46.

4. Id. at 646 .

5. Id. at 647 .

6. Id. at 646 . 
$1966 .^{7}$

In 2016, Landowners hired a contractor to build a fence around their property, which included part of the Driveway. ${ }^{8}$ In response, Claimant's tenant blocked the contractor from installing the fence, and Landowners responded by filing a complaint. ${ }^{9}$ Landowners' complaint sought a restraining order based on trespass to enjoin Claimant from using the Driveway and damages relating to the fencing contract. ${ }^{10}$ Claimant counterclaimed for adverse possession to a portion of the driveway adjacent to her property, a prescriptive easement, and an implied easement by prior use for use of the entire Driveway. ${ }^{11}$ Applying the factors provided in Fraley v. Minger and Celebration Worship Ctr., v. Tucker, the trial court ruled that Claimant had established her adverse possession, prescriptive easement, and easement by prior use counterclaims. ${ }^{12}$ After trial, Landowners filed a motion to correct error based on their contention that the trial court's judgments were "incompatible legal theories." ${ }^{13}$ Specifically, Landowners argued it was impossible for the trial court to both grant easements to Claimant's use of the Driveway while also granting her adverse possession claim to the Driveway. ${ }^{14}$ The trial court denied Landowners' motion to correct error and Landowners appealed the trial court's findings. ${ }^{15}$

The Court of Appeals affirmed the trial court's judgment first by assessing the "Fraley factors" in order to establish adverse possession. ${ }^{16}$ Analyzing these factors, the Court concurred with the trial court's findings that Claimant had (1) control over the property in question; (2) "intent to claim full ownership of the tract"; (3) actual or constructive notice to Landowners through Claimant's actions toward the property; (4) satisfied the other three elements for the required tenyear period of time; and also satisfied the statutory requirement of Indiana Code $\S 32-21-7-1$, requiring that an adverse possessor "pay all taxes and special assessments" due on the property, to establish Claimant's adverse possession over a portion of the Driveway. ${ }^{17}$ The Court similarly upheld the trial court's ruling on Claimant's prescriptive easement, reasoning that the same Fraley factors had been satisfied during the twenty-year period required for establishing prescriptive easements under Indiana Code $\S 32-23-1-1 .^{18}$ In affirming these findings, the Court noted that the Landowners' challenge to the trial court's judgment

7. Id. at 647 .

8. Id..

9. $I d$.

10. Id. at 648 .

11. Id.

12. Id. at 649-50; Fraley v. Minger, 829 N.E.2d 476 (Ind. 2005); Celebration Worship Ctr., Inc. v. Tucker, 35 N.E.3d 251 (Ind. 2015).

13. Hardin, 125 N.E.3d at 650.

14. Id.

15. $I d$.

16. Id. at 652 .

17. Id. at 651-54.

18. Id. 
"seem[ed] to be premised on the mistaken understanding that the trial court had determined that [Claimant] had both adverse possession and a prescriptive easement of the entire gravel driveway." ${ }^{19}$ The Court then clarified that the trial court's ruling had only established adverse possession for Claimant for part of the Driveway, while the easement pertained to the remainder of the Driveway for ingress and egress. ${ }^{20}$ The Court also rejected Landowners' argument that the trial court's ruling should be reversed because Claimant's use of the Driveway was merely permissive, thus defeating the intent element for adverse possession. ${ }^{21}$ In rejecting this argument, the Court reasoned that reversing would essentially require the appellate court to reweigh the creditability of witnesses at trial, something the Court declined to do. ${ }^{22}$ The Court also rejected Landowners' argument that Claimant was not the only person who used the Driveway, supposedly defeating her adverse possession claim. ${ }^{23}$ The Court rejected this argument again on the basis of Landowners' confusion between the boundaries of the adversely possessed property and the rest of the Driveway for which an easement had been established, finding that the usage of the Driveway by others for ingress and egress pertained to the easement alone and did not impact the adversely possessed section. ${ }^{24}$ Finally, the Court also rejected Landowners' argument that Claimant did not substantially comply with the property tax requirements of adverse possession because she could not have had a "good faith belief that she had paid taxes for the gravel driveway." ${ }^{25}$ In rejecting this final argument, the Court pointed out that Claimant was not required to pay taxes on the entire Driveway; rather, she was only required to pay the taxes for the section of the driveway for which she believed to be hers.

\section{ANNEXATION}

\section{A. Marsh v. Town of Dayton}

In Marsh v. Town of Dayton, ${ }^{26}$ the Court of Appeals considered a challenge regarding the adequacy of a fiscal plan for a proposed annexation under Indiana Code $\S 36-4-3-13$. The complaint was filed by a resident and taxpayer (the "Plaintiff") of the Town of Dayton, Indiana (the "Town"), shortly after the Town approved a resolution for the adoption of a fiscal plan for the annexation of about fifty-five acres of land that was slated for construction of a residential subdivision. ${ }^{27}$ The Plaintiff asserted that the fiscal plan was inadequate because

19. Id. at 652 .

20. Id. at 652-53.

21. Id. at 653 .

22. Id.

23. $I d$.

24. $I d$.

25. Id. at 654 .

26. Marsh v. Town of Dayton, 115 N.E.3d 504 (Ind. Ct. App. 2018).

27. Id. at 505 . 
it "[did] not disclose the source of funding for the possible sidewalk extensions from the new subdivision to the existing sidewalks," nor did it include "the source of funding for the construction and extension of sewer and water main services from the new subdivision to the existing utilities." ${ }^{28}$ The trial court dismissed the complaint for failure to state a claim.

The Court of Appeals affirmed the trial court's dismissal, finding the Plaintiff's claims meritless. Indiana Code $\S 36-4-3-13$ requires a municipality to adopt a written fiscal plan that includes, among other things, "[t]he cost estimates of planned services to be furnished to the territory to be annexed" and "[t]he method or methods of financing the planned services," and "services of a capital improvement nature," which includes sewer facilities and water facilities, "will be provided to the annexed territory within three (3) years after the effective date of the annexation." 29 "The plan must present itemized estimated costs for each municipal department or agency" and "must explain how specific and detailed expenses will be funded and must indicate the taxes, grants, and other funding to be used." ${ }^{30}$

The Court of Appeals quickly dismissed the Plaintiff's argument regarding the lack of funding sources for the capital improvements because the annexation plan, in fact, did contain such information. ${ }^{31}$ The Court of Appeals also rejected Plaintiff's other argument, holding the Town had no plans to construct sidewalk extensions and the Town is not mandated to do so. Because there is no authority requiring that a fiscal plan include estimated costs and specify funding sources for "purely hypothetical projects," 32 the Court of Appeals found the Plaintiff's complaint meritless and upheld the dismissal.

\section{AUTHORITY OF AN AGENT}

\section{$A$. GO Properties, LLC v. Ber Enterprises, LLC}

In GO Properties, $L L C$ v. BER Enterprises, $L L C,^{33}$ the Court of Appeals held that an individual (the "Unauthorized Agent") did not have actual or apparent authority to sell property on behalf of a limited liability company (the "Principal"), which made the sale of the property void. ${ }^{34}$ The Principal, a limited liability company ("LLC"), had two members which were both limited liability companies. The Principal owned real property located in Indianapolis, Indiana (the "Property"). The Unauthorized Agent was the sole member of one of the member LLCs. The other member LLC was the designated "Member Manager"

28. Id. at 507 .

29. Id. at 507 (citing IND. CODE § 36-4-3-3.1(b) (2019); IND. CODE §§ 36-4-3-13(d)(1), (2), (5) (2019)).

30. Id. at 506-07 (citing IND. CoDE $\S \S 36-4-3-13(d)(1)-(2)(2019)$ ).

31. Id. at 507 .

32. Id.

33. Go Properties, LLC v. BER Enterprises, LLC, 112 N.E.3d 200 (Ind. Ct. App. 2018).

34. Id. at 205. 
of the Principal and, pursuant to the Principal's operating agreement, "had the sole authority to sign agreements and other instruments on behalf of [the Principal] without the signature and/or written consent of any other Member." ${ }^{\prime 35}$ The Unauthorized Agent was not authorized "to do any business on behalf of [the Principal]." ${ }^{36}$

On August 1, 2013, the Unauthorized Agent began the process of selling the Property to a third-party buyer. ${ }^{37}$ The Unauthorized Agent, without any authority from or communication with the Principal, filed to name herself as the registered agent and changed the Principal's principal address to the Agent's home address with the Indiana Secretary of State. ${ }^{38}$ The Unauthorized Agent hired a title company to perform a title examination of the Property and act as the closing agent for the transaction. The sale of the Property closed on August 13, 2013, and the Unauthorized Agent executed a deed from the Principal to a third-party buyer. $^{39}$ The third-party buyer subsequently conveyed the Property to a different third-party buyer.

On April 16, 2015, the Principal filed a complaint against the third-party buyers, seeking quiet title to the Property. The trial court granted the third-party buyers' motion for summary judgment over the Principal's cross-motion, reasoning that the Unauthorized Agent "appeared to have the authority to execute the instruments" 40 and favored "[t]he desirability of stability and predictability in the field of property law." ${ }^{41}$

The Court of Appeals reversed and remanded the trial court's grant of summary judgment for the third-party buyers. ${ }^{42}$ The Court reasoned that the thirdparty buyers' deeds were void because the Unauthorized Agent had neither actual nor apparent authority. ${ }^{43}$ The Court held that "[a]pparent authority is the authority that a third person reasonably believes an agent to possess because of some manifestation from the agent's principal." ${ }^{44}$ To find apparent authority, "it is essential that there be some form of communication, direct or indirect, by the principal, which instills a reasonable belief in the mind of the third party." ${ }^{, 45}$ The Court reasoned that no apparent authority existed because the title company only relied on the Unauthorized Agent's representations, rather than reviewing the Principal's operating agreement or requiring that the Principal deliver a written consent authorizing the transaction. ${ }^{46}$

35. Id. at 202.
36. Id.
37. Id.
38. Id.
39. Id.
40. Id. at 203.
41. Id.
42. Id. at 205.
43. Id.
44. Id. at 204.
45. Id.
46. Id. at $204-05$.




\section{DAMS}

\section{A. John E. Moriarity v. Indiana Department of Natural Resources}

In Moriarity v. Indiana Department of Natural Resources, ${ }^{47}$ the Supreme Court considered (1) whether the Indiana Department of Natural Resources (the "DNR") properly exercised jurisdiction over Mae and John Moriarity's (the "Owners") dam, (2) whether the DNR "present[ed] substantial evidence supporting its classification of the dam as a high-hazard dam," and (3) whether Owners can "modify their dam to remove it from DNR's future jurisdiction." 48

The DNR issued a Notice of Violation ("NOV") to the Owners "describing numerous violations of the Dam Safety Act" and ordering the Owners to "make certain changes to their pond and dam." ${ }^{\text {49 }}$ The Dam Safety Act governs "the safety of certain dams in, on, or along streams in Indiana." ${ }^{50}$ Owners of these dams have an affirmative obligation under the act to properly maintain them. The Act also gives the DNR supervisory and enforcement power to ensure owners properly maintain their dams. ${ }^{51}$ Following the Owners' petition for administrative review, the administrative law judges ruled in favor of the DNR and the Natural Resources Commission (the "NRC"). ${ }^{52}$ The NRC issued a Final Order requiring the Owners to address the issues with their dam and pay civil penalties. ${ }^{53}$ The Owners sought judicial review, and both the trial court and the Court of Appeals affirmed the NRC Final Order. ${ }^{54}$

First, the Supreme Court held that the DNR has jurisdiction over the Owners' dam based on its location on a stream of Indiana. ${ }^{55}$ The Dam Safety Act gives the DNR jurisdiction over dams "in, on, or along the rivers, streams, and lakes of Indiana," and the Court held that an agency's interpretation of a statute will be accepted if it is reasonable. ${ }^{56}$ Although "stream" is not specifically defined in the statute, the Court found the DNR's interpretation of the word is consistent with the plain meaning of the word and therefore reasonable. ${ }^{57}$

Second, the Court held that the DNR presented substantial evidence in classifying the Owners' dam as high-hazard. ${ }^{58}$ The Dam Safety Act defines a dam as high-hazard if it is "a structure the failure of which may cause the loss of life

47. Moriarity v. Ind. Dep't of Nat. Res.,113 N.E.3d 614 (Ind. 2019).

48. Id. at 617 .

49. Id. at 618 .

50. Id. at 620 (citing IND. CodE $\S 14-27-7.5-8(\mathrm{a})(1)$ (2019)).

51. Id.; see also IND. CODE $\S 14-27-7.5-7$ (a).

52. Moriarity, 113 N.E.3d at 618.

53. Id.

54. Id.

55. Id. at 620 .

56. Id. at 620-21 (quoting IND. CoDE $\S 14-27-7.5-8(\mathrm{a})(1)$ ).

57. Id. at 621 .

58. Id. at 622-23. 
and serious damage to the homes, industrial and commercial buildings, public utilities, major highways, or railroads." ${ }^{59}$ The DNR presented testimony of employees and an inundation study conducted on the dam to support its conclusion. ${ }^{60}$ Specifically, the presence of a church, a home, and road below the dam justified the DNR's finding that the dam was high-hazard. ${ }^{61}$

Finally, the Court held that the Owners may, in compliance with the trial court's order, modify their damn to remove it from DNR jurisdiction. ${ }^{62}$ The Owners sought to modify the trial court's order enforcing the Final Order to "include an express provision allowing them to change their dam so that it no longer falls within the DNR's Dam Safety Act jurisdiction." ${ }^{63}$ The Court held that it was unnecessary for the Final Order to be modified, since the Owners could unilaterally modify their dam until it no longer falls within the jurisdiction of the Act. Specifically, the dam would need to be less than twenty feet in height and impound a volume of no more than one hundred acre-feet of water (along with some other statutory requirements). ${ }^{64}$

\section{EASEMENTS, COVENANTS, AND TITLE ISSUES}

\section{A. Newforth v. Bault}

In Newforth v. Bault, ${ }^{65}$ the Court of Appeals considered whether an easement owner's proposed drives were situated within the easement area, and whether the easement permitted the owner's use of semi-tractor trailers. Bault (the "Easement Owner") requested permission from the Newforths (the "Property Owners") to install drives over part of the easement area in order to connect his property to an access road for use in his mulch business. ${ }^{66}$ The Property Owners objected, and the Easement Owner brought an action seeking both declaratory relief and an injunction to enjoin the Property Owners from interfering with his right to install a culvert pipe and two graded gravel areas within the easement area. ${ }^{67}$ The trial court entered a declaratory judgment for the Easement Owner. The Property Owners appealed. ${ }^{68}$

The Court of Appeals affirmed the trial court's decision and held that the Easement Owner's proposed drives were situated within the easement area, that the proposed drives did not extend onto any property of the Property Owners not subject to an easement, and that Easement Owner's use of semi-tractor trailers

59. Id. at 622 (quoting IND. CODE $§ 14-27-7.5-8(\mathrm{~b})(1)$ ).

60. Id. at 623 .

61. Id.

62. Id. at 623-24.

63. Id.

64. Id.; see also IND. CoDE $\S 14-27-7.5-1(1)$.

65. Newforth v. Bault, 120 N.E.3d 594 (Ind. Ct. App. 2019).

66. Id. at 598 .

67. Id.

68. Id. at 596. 
was foreseeable. ${ }^{69}$ The Court noted that Easement Owners (the dominant estate) generally possess all rights incident to the enjoyment of the easement. ${ }^{70}$ "The owners of property over which the easement passes, known as the servient estate, may use their property in any manner and for any purpose which comports with the enjoyment of the easement, and the dominant estate cannot disturb that use." ${ }^{\prime 1}$ Servient owners may not use their land to obstruct the easement or interfere with the enjoyment of it by the dominant estate. ${ }^{72}$ However, the dominant estate cannot impose additional burdens upon the servient estate, just as the servient estate cannot "materially impair or unreasonably interfere with the use of the easement." "73 In reaching its conclusions, the Court noted that, "Indiana cases have held that the owner of an easement possesses all rights necessarily incident to the enjoyment of the easement, and that the owner may make such repairs, improvements, or alterations as are reasonably necessary to make the grant of the easement effectual." ${ }^{\text {74 }}$

As an initial matter, the Court found that the proposed drives were located within the easement area and did not extend onto the Property Owners' property because the southern boundary of the Easement Owner's property coincided with the northern boundary of the easement area. ${ }^{75}$ The Court also found that the proposed drives were reasonably necessary for the Easement Owner's use of the easement and were consistent with the easement's purpose of providing industrial vehicles with safe and sufficient access to and from the rural industrial park parcels nearby.$^{76}$ The Court additionally found that it was reasonably foreseeable at the time the easement was created that it would be utilized by semi-tractor trailers and heavy equipment vehicles and that the Easement Owner's intended use would not subject the Property Owners to additional burdens nor impair or unreasonably interfere with their use and enjoyment of their property. ${ }^{77}$

\section{B. RCM Phoenix Partners, LLC v. 2007 East Meadows, LP}

In RCM Phoenix Partners, LLC v. 2007 East Meadows, $L P,{ }^{78}$ the Court of Appeals considered the absolute privilege of a lis pendens notice in relation to a slander of title claim. In July 2007, RCM Phoenix Partners, LLC ("Seller") entered into a Purchase and Sale Agreement (the "Purchase Agreement") with Eureka Holdings Acquisitions, LLP ("Eureka") for the purchase of an apartment

69. Id. at 598.

70. Id. at 600 (citing Rehl v. Billetz, 963 N.E.2d 1, 6 (Ind. Ct. App. 2012)).

71. Id. (emphasis added).

72. Id. (citing Rehl, 963 N.E.2d at 6-7).

73. Id. (citing Rehl, 963 N.E.2d at 7).

74. Id.

75. Id. at 601 .

76. Id. at 600,602 .

77. Id. at 598 .

78. RCM Pheonix Partners, LLC v. 2007 E. Meadows, LP, 118 N.E.3d 756 (Ind. Ct. App. 2019). 
community in Indianapolis (the "Property"). ${ }^{79}$ Eureka assigned the Purchase Agreement to 2007 East Meadows, LP ("Buyer") in September 2007. ${ }^{80}$ The assignment required Buyer to assume Seller's existing mortgage on the Property, and due to delays in assuming the mortgage, the parties agreed to several extensions on the closing date in the Purchase Agreement. ${ }^{81}$ In the meantime, Buyer learned of an Indiana Housing Authority ("IHA") civil enforcement action against Seller regarding the condition of the Property. ${ }^{82}$

Buyer still had not received approval for assumption of Seller's mortgage in January 2008, and Seller denied Buyer's request for a closing date extension. ${ }^{83}$ Buyer filed suit against Seller in Texas alleging breach of contract and fraud based on the pending IHA enforcement action. ${ }^{84}$ Buyer filed its first lis pendens notice of the Texas lawsuit on January 25, 2008. ${ }^{85}$ On July 31, 2008, Seller filed suit in Indiana claiming Buyer breached the Purchase Agreement, entitling Seller to keep the earnest money deposit made by Buyer. ${ }^{86}$ This lawsuit prompted Buyer to file an amended lis pendens notice of both the pending Indiana and Texas lawsuits. ${ }^{87}$

The Texas suit was dismissed for lack of personal jurisdiction. ${ }^{88}$ In the Indiana case, Buyer "filed its answer and counter-claims against [Seller] for breach of contract and fraud but did not raise any affirmative defenses." ${ }^{89}$ Seller filed a supplemental complaint adding a slander of title claim to which Buyer responded raising seven affirmative defenses but did not allege that its lis pendens notice was privileged as a matter of law. ${ }^{90}$ After learning that Seller planned to sell the Property to a third party, Buyer filed its third amended lis pendens notice on December 6, 2013. ${ }^{11}$ The court granted summary judgment in favor of Seller for Buyer's counter-claims on June 26, 2014. ${ }^{22}$ The Court of Appeals affirmed the summary judgment for Seller on the counter-claims, and the only remaining claims were the retention of the earnest money deposit and slander of title. ${ }^{93}$ The case was remanded, and the trial court found for Seller on the retention of the earnest money but found for Buyer on the slander of title claim, concluding that

79. Id. at 758 .

80. Id.

81. Id.

82. Id.

83. Id.

84. Id.

85. Id.

86. $I d$.

87. Id.

88. Id. at 758-59.

89. Id. at 759 .

90. Id.

91. Id.

92. Id.

93. Id. 
Buyer's incorrect statements were made on a good faith basis. ${ }^{94}$ Seller appealed the denial of its slander of title claim. ${ }^{95}$

The issues raised on appeal were whether Buyer waived its claim of absolute privilege regarding the lis pendens notice by raising it for the first time on appeal and whether the court erred in denying Seller's slander of title claim. The Court of Appeals found that an appellee who seeks to affirm the trial court's decision may present an argument on appeal that was not raised at trial, and, therefore, Buyer could raise any argument in support of the trial court's decision to deny the slander of title claim. ${ }^{96}$ The Court of Appeals also found that Buyer correctly filed its lis pendens notice according to Indiana statute, ${ }^{97}$ and the statements made in the notice are absolutely privileged. ${ }^{98}$ A party with an interest in a property is required to file a lis pendens notice to inform interested third parties of potential issues with the title. ${ }^{99}$ Therefore, Buyer may not be held liable for slander of title for properly filing the lis pendens notice. ${ }^{100}$ The Court of Appeals concluded that the trial court correctly denied Seller's slander of title claim based on Buyer's lis pendens notice. ${ }^{101}$

Because Buyer was required to file a lis pendens notice by law and properly did so, the statements made in the notice were absolutely privileged, and Buyer cannot be held liable for slander of title as a matter of law, the Court of Appeals affirmed the trial court's judgment denying Seller's slander of title claim.

\section{Town of Ellettsville v. DeSpirito}

In Town of Ellettsville v. DeSpirito, ${ }^{102}$ the Indiana Supreme Court considered whether to reject the long-standing common law rule that relocating fixed easements requires all parties' consent, and whether to adopt the restatement approach that permits unilateral relocation upon satisfaction of a factors test. The original property owner recorded a plat dividing the property into two parcels. The plat designated a utility easement across one parcel in favor of the other. The owner of the servient estate filed a petition with the Town of Ellettsville Plan Commission (the "Commission") to relocate the easement on its property to increase the buildable area, notably agreeing to cover all of the costs to do so. The dominant estate-holder opposed the relocation. Nevertheless, the Commission granted the servient estate's petition, reasoning that the relocation would result in minimal harm to the dominant estate and would maximize the use of the

94. Id.

95. Id.

96. Id. at 761 (citing Ind. Bureau of Motor Vehicles v. Gurtner, 27 N.E.3d 306, 312 (Ind. Ct. App. 2015)).

97. IND. CODE $\S 32-30-11-3$.

98. RCM Phoenix Partners, 118 N.E.3d at 762.

99. Id.

100. Id.

101. Id.

102. Town of Ellettsville v. DeSpirito, 111 N.E. 3d 987 (Ind. 2018). 
servient estate. ${ }^{103}$

The dominant estate-holder appealed to an Indiana trial court, which reversed the Commission's ruling. The trial court applied Indiana's long-standing common law rule that modifying fixed easements requires both parties' consent. On appeal, the Indiana Court of Appeals reversed the trial court and held that the common law rule should be rejected in favor of the more "modern" Restatement approach. ${ }^{104}$ The "modern" approach allows the servient estate-holder to "make reasonable changes in the location or dimensions of an easement" at their expense if it does not "(a) significantly lessen the utility of the easement, (b) increase the burdens on the owner of the easement in its use and enjoyment, or (c) frustrate the purpose for which the easement was created." 105 The Court of Appeals reasoned that the common law rule turns an easement into a possessory interest rather than a mere easement because it grants the dominant estate such control over the servient estate's property. ${ }^{106}$ The Indiana Supreme Court reversed the decision of the Court of Appeals and rejected the Restatement approach.

Before considering the main issue, the Indiana Supreme Court explained that an easement is considered "fixed" if the instrument creating the easement provides a specific location or if the law requires a specific location for the easement. ${ }^{107}$ Although the distance of the easement to the boundaries was not indicated on the plat, the Supreme Court reasoned that the easement was fixed because the easement's width could be determined by measuring the marked lines on the plat with a ruler. ${ }^{108}$

On the other hand, the Restatement approach was unclear and inconsistent. ${ }^{109}$ Based upon a plain-meaning interpretation, the Restatement does not apply to fixed easements. The Restatement provision, "[e]xcept where the location and dimensions are determined by the instrument or circumstances surrounding

103. Id. at 989 .

104. Id.

105. Id. at 992-93 (quoting Restatement (Third) Of Prop.: Servitudes $§ 4.8(3)$ (Am. Law INST. 2000), which states:

Except where the location and dimensions are determined by the instrument or circumstances surrounding creation of a servitude, they are determined as follows: (1) The owner of the servient estate has the right within a reasonable time to specify a location that is reasonably suited to carry out the purpose of the servitude; (2) The dimensions are those reasonably necessary for enjoyment of the servitude; (3) Unless expressly denied by the terms of an easement, as defined in $\S 1.2$, the owner of the servient estate is entitled to make reasonable changes in the location or dimensions of an easement, at the servient owner's expense, to permit normal use or development of the servient estate, but only if the changes do not (a) significantly lessen the utility of the easement, (b) increase the burdens on the owner of the easement in its use and enjoyment, or (c) frustrate the purpose for which the easement was created.)

106. Id. at 989 .

107. Id. at 990 .

108. Id. at 991 .

109. Id. at 992 . 
creation of a servitude, they are determined as follows [. . .]," conveyed the idea that the Restatement is limited to easements that are not fixed or "determined." 110 Further, the drafter's expository example was inconsistent with the drafter's intent. The example illustrated in the expository example relates to a fixed easement under the common law, yet the drafter's intent was to illustrate an easement that could be relocated unilaterally. ${ }^{111}$

Ultimately, the Indiana Supreme Court reaffirmed Indiana's common-law rule that the servient and dominant estate-holder must both consent to relocate or both consent to modify a fixed easement's location. The Court explained, "Property rights in Indiana are not so flimsy that they may be modified or eliminated if their exercise impedes what is thought to be a more productive or worthwhile use of land." 112 The Court highlighted four policy arguments for its conclusion. First, parties bargain over the location and easement type, so one party would be deprived of its bargain if the other could unilaterally alter the agreement. Second, the common law approach rarely leads to litigation, and it provides a bright-line rule: Relocating an easement requires the consent of both parties. ${ }^{113}$ Allowing the servient estate holder to relocate an easement under the Restatement approach would increase litigation based on "reasonableness issues." "114 Third, Justice Scalia, in a United States Supreme Court plurality opinion, cautioned courts against modifying a common law approach that would alter or eliminate a settled property right. ${ }^{115}$ By retaining the common law rule, the Supreme Court does not have to consider whether the Restatement clause at issue here alters or eliminates a settled property right in violation of the Takings Clause. ${ }^{116}$ Last, the common law approach is economically efficient because it requires the servient and dominant estate holders to cooperate. The Restatement approach, however, would make bargaining costlier and deter efficient resource usage. ${ }^{117}$

\section{William J. Huff, II Revocable Trust Declaration v. Michael O. Cain}

In William J. Huff, II Revocable Trust Declaration, Dated June 28, 2011 v. Michael O. Cain, ${ }^{118}$ the Court of Appeals considered the broadness of the preliminary injunction preventing the dominant easement holders from harvesting timber on their landlocked property. Michael O. Cain and Linda A. Raymond (the

110. Id. at 992-93 (quoting Restatement (ThiRd) of Prop.: Servitudes $§ 4.8$ (Am. Law INST. 2000)).

111. Id. at 994 .

112. Id. at 988 .

113. Id. at 995 .

114. Id.

115. Id. at 995-96.

116. Id. at 996 .

117. Id.

118. William J. Huff, II Revocable Trust Declaration, Dated June 28, 2011 v. Michael O. Cain, 120 N.E.3d 1029 (Ind. Ct. App. 2019). 
"Landowners") sought injunctive relief against Huff Real Estate (the "Grantee") to prevent the Grantee from using an easement for any activity other than the construction and development of single-family residences. ${ }^{119}$ The Landowners objected to the Grantee's use of the driveway easement to harvest timber because of the increased heavy machinery traveling on the driveway. ${ }^{120}$ The trial court granted the Landowners' preliminary injunction, enjoining the Grantee from using the easement "for commercial logging or for hauling logs or trees, or forestry activity." "21 The injunction also enjoined the Grantee from using the easement for anything other than construction and development of single-family homes. ${ }^{122}$

The issue on appeal was whether the trial court abused its discretion in issuing the injunction against the Grantee. The Court of Appeals held that the injunction was overbroad in preventing the Grantee from using the easement for any forestry activity. ${ }^{123}$ The enjoinment of "forestry activity" appeared to prevent the Grantee from exercising its rights under the easement because some type of forestry activity would be necessary to construct the single-family residences. ${ }^{124}$ Additionally, because the Grantee's property was landlocked, utilizing the easements would be necessary for prudent logging, which was essential for the reasonable use of the property. ${ }^{125}$

Since "forestry activity" was necessary for the Grantee to exercise its rights under the easement, the Court of Appeals held that the trial court's preliminary injunction enjoining the Grantee from conducting forestry activity was overbroad and should be vacated. ${ }^{126}$

\section{EMINENT DOMAIN}

\section{A. Guzzo v. Town of St. John}

In Guzzo v. Town of St. John, ${ }^{127}$ the Court of Appeals considered for purposes of an eminent domain action whether (1) a previously occupied and presently maintained residence qualifies as "occupied" under Indiana Code $\S 32-24-4.5-$ $8(2)$, and (2) what qualifies as "agricultural land" under Indiana Code $\S 32-24-$

119. Id. at 1031 .

120. Id. at 1033-34.

121. Id. at 1035 .

122. Id.

123. Id. at 1037.

124. Id.

125. Id. at 1038 .

126. Id. at 1038-39 (Riley, J., dissenting from the denial of the preliminary injunction because the Grantee was not currently exercising the rights in the easement and the scope of a preliminary injunction is to maintain the status quo).

127. Guzzo v. Town of St. John, 112 N.E.3d 1159 (Ind. Ct. App. 2018). Please note, as of the time of publication of this Article, the Supreme Court vacated this Opinion pursuant to Guzzo v. Town of St. John, 131 N.E.3d 179 (Ind. 2019). 
4.5-8(1). In this case, an owner of real property (the "Landowner") located in the Town of St. John, Indiana (the "Town") owned two parcels of land (the "Property"). The Property consisted of approximately eight acres of wooded, untillable land, and contained a vacated house and a barn, along with other improvements. ${ }^{128}$ The Landowner mowed the lawn and repaired the vacated house but never used the Property for agricultural purposes. ${ }^{129}$ In 2014, in connection with a nearby development, the Town issued a "Uniform Property Acquisition Offer" to the Landowner, seeking to purchase the Property for a "Roadway Improvement and Economic Development Project." 130 The Landowner rejected the offer, so the Town instituted condemnation proceedings. ${ }^{131}$ On July 31, 2014, the trial court approved and entered an agreed order of appropriation of real estate. $^{132}$ Over the summer, court-appointed appraisers valued the Property at $\$ 745,000 .{ }^{133}$ That fall, the Property was transferred to the Town, and the Town deposited the appraised amount with the trial court.

Landowner filed a motion of partial summary judgment, arguing that the Property should be subject to "enhanced compensation" under Indiana Code § 3224-4.5-8. ${ }^{134}$ Under this section of the Indiana Code, if the Property were a "parcel of real property occupied by the owner as a residence," the Landlord would be entitled to receive 150 percent of the Property's fair market value. ${ }^{135}$ Additionally, if the Property were "agricultural land," the Landlord would be entitled to receive 125 percent of the Property's fair market value. ${ }^{136}$ The trial court concluded that the Property was neither a parcel of real property "occupied by an owner as a residence" nor "agricultural land," 137 and thus did not qualify for compensation greater than 100 percent of fair market value under the Code. ${ }^{138}$

The Court of Appeals affirmed the trial court's ruling. ${ }^{139}$ The Court determined the meaning of the word "occupied" requires the parcel to be "occupied by an owner as a residence at the time of the taking." 140 The Court rejected the Landowner's argument that prior occupation of the house is enough, determining that such a reading would go against the plain meaning of the statute and against legislative intent. ${ }^{141}$ Additionally, the Court declined to formulate a general rule for what constitutes occupancy, but rejected the argument that

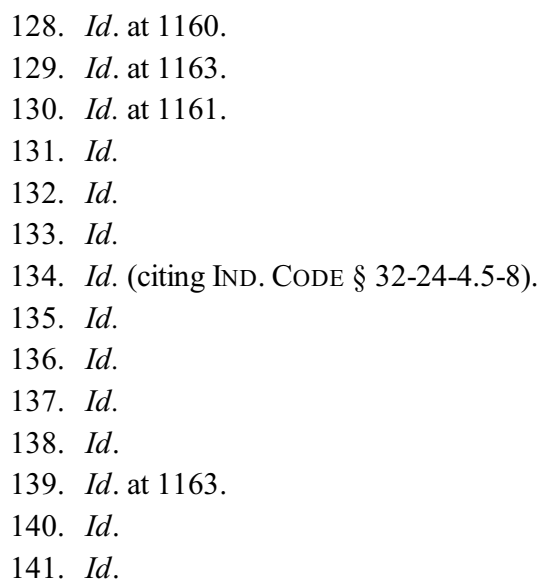


mowing the land and repairing the residence constituted "occupancy." 142 The Court also affirmed the trial court's ruling that the Property was not "agricultural land." 143 The Court acknowledged that the statute refers to the land's character but determined that "agricultural" character is due to agricultural use of the land because " "agriculture' is an activity rather than some inherent characteristic such as soil type or location." 144 Since the Property had no agriculture occurring at the time of the taking, it did not qualify as "agricultural land" under Indiana Code $\S$ $32-24-4.5-8(1){ }^{145}$

\section{HOMEOWNERS’'ASSOCIATIONS}

\section{A.. Village Pines at Pines of Greenwood Homeowners Ass'n v. Pines of Greenwood, LLC ${ }^{146}$}

In Village Pines at Pines of Greenwood Homeowners Ass'n v. Pines of Greenwood, $L L C,{ }^{147}$ the Court of Appeals considered whether Arbor Homes, LLC and Pines of Greenwood, LLC (the "Developers") violated the procedure for amending covenants as prescribed by The Declaration of Covenants, Conditions and Restrictions and Grant and Reservation of Easements (the "Declaration"). The Developers recorded the Declaration for the Village Pines at the Pines of Greenwood (the "Development") in January 2000. ${ }^{148}$ Section 12.2 of the Declaration provided for its amendment, stating that any "resolution shall be adopted by the vote ... of Members representing not less than sixty-seven percent (67\%) of the voting power of the Association." ${ }^{149}$ The Declaration further provided that the Developers could amend the Declaration without approval from the Homeowner's Association (the "Association") in order "to correct clerical or typographical errors in [the] Declaration" under Section 12.3 of the Declaration. ${ }^{150}$ Furthermore, Article V of the Declaration provided for the Homeowners Association's "Maintenance Funds and Assessments," including a provision that the Developers, along with the other property owners, "shall be deemed to covenant and agree to pay to the Association, Annual Assessments and other amounts as required or provided for in this Declaration." ${ }^{151}$ In July of 2007, the Developers recorded the first amendment to the Declaration under the

142. $I d$.

143. Id. at 1164 .

144. Id.

145. Id.

146. See "Easements, Covenants and Title Issues" Subsection on page 10.

147. Vill. Pines at Pines of Greenwood Homeowners Ass'n v. Pines of Greenwood, LLC, 123 N.E.3d 145 (Ind. Ct. App. 2019).

148. Id. at 147 .

149. Id. at 149 .

150. Id. at 150 .

151. Id. at 152 . 
procedures established in Section 12.2. ${ }^{152}$ In July 2008, the Developers recorded the second amendment to the Declaration, the effect of which was to remove Developers' obligation to contribute to the "Association's Common Expenses" under the Declaration. ${ }^{153}$ When adopting the second amendment, the Developers did not follow the prescribed procedure for amendment under Section 12.2; rather, the amendment was made pursuant to Section 12.3 of the Declaration intended to correct "clerical and typographical errors." 154

In November 2011, the Association filed suit against the Developers for recording the second amendment, asserting claims for breach of contract and breach of fiduciary duty. ${ }^{155}$ The trial court found for the Developers on the Association's breach of fiduciary duty claim, reasoning that the two-year statute of limitations had run out. ${ }^{156}$ The trial court similarly found for the Developers regarding the Association's breach of contract claim, reasoning, "the [Association] 'did not suffer any actual damages because its budget was fully funded every year." "157

On appeal, the Court affirmed the trial court's conclusion that the statute of limitations had run out on the Association's claim of breach of fiduciary duty, reasoning that "ascertainable damage had occurred [to the Association] that, in the exercise of ordinary diligence, could have been discovered prior to the expiration of the applicable statute of limitation period."158 Regarding the Association's claim for breach of contract, the Court reversed the trial court's finding that, despite the fact the Developers did not pay assessments from 2000 to 2009 as a result of their unilateral second amendment, the Association did not suffer any damages. ${ }^{159}$ In reversing this finding, the Court rejected the Developers' argument that the second amendment "merely corrected clerical or typographical errors" 160 and also rejected the argument accepted by the trial court that the second amendment "did not increase any burden on [the Association]" because its " "annual budgets were fully funded every year." 161 In rejecting these arguments, the Court noted that "the articles of incorporation and bylaws of a non-profit corporation [such as the Declaration here] constitute a contract between the corporation and its members." ${ }^{162}$ Further, the Court found that under a plain reading of the Declaration, the Developers were required to contribute to the annual assessments and failed to do so. ${ }^{163}$ Thus, the Court ruled that because

152. Id. at 151 .

153. Id. at 151-52.

154. Id. at 151.

155. Id. at 6 .

156. Id. at 8 .

157. Id. at 154 .

158. Id. at 155 .

159. Id. at 157.

160. Id.

161. Id.

162. Id.

163. Id.. 
the second amendment violated Section 12.2 of the Declaration by failing to be properly adopted by the requisite 67 percent of the Association, the Developers owed assessments for prior years and reversed and remanded in favor of the Association's breach of contract claim in order to determine damages. ${ }^{164}$

\section{INSURANCE}

\section{A. Berkshire Hathaway Homestate Insurance Company v. Basham}

In Berkshire Hathaway Homestate Insurance Company v. Basham ${ }^{165}$ the Court of Appeals interpreted the meaning of the terms "building" and "completed addition" contained within an insurance policy contract by considering the ambiguity of each term. Berkshire Hathaway (the "Insurer"), issued an insurance policy (the "Policy"), to Basham (the "Insured"), to cover fifteen rental properties across Indiana, one of which included a house and a detached garage. ${ }^{166}$ During the period covered by the Policy, a fire burned down the garage and damaged the house. ${ }^{167}$ The Insurer paid the Insured's claim for the damage to the house, but denied the claim for damage to the garage, stating that the detached garage did not meet the definition of covered property outlined in the Policy, which included "the building" and any "completed additions." against the Insurer for wrongful denial of the insurance coverage. ${ }^{169}$ The court determined that the policy was ambiguous and interpreted the policy in the Insured's favor, concluding that the Policy covered damage to the garage. ${ }^{170}$ The Insurer appealed from the court's grant of summary judgment in favor of the Insured. ${ }^{171}$

The Court of Appeals affirmed the decision of the trial court and held that the policy was ambiguous, and the detached garage was covered property under the "completed additions" term within the Policy. ${ }^{172}$ In reaching its conclusion, the Court noted that terms in an insurance policy are "interpreted from the perspective of an ordinary policyholder of average intelligence," and that "[i]f reasonably intelligent persons may honestly differ as to the meaning of the policy language, the policy is ambiguous." ${ }^{" 173}$ The Court reasoned that the garage was not covered under the policy as "the building" because that portion of the policy was written in the singular and because the plain language of the policy describes "the

164. Id.

165. Berkshire Hathaway Homestate Insurance Company v. Basham, 113 N.E.3d 630 (Ind. Ct. App. 2018), reh'g denied (Dec. 11, 2018), transfer denied, 124 N.E.3d 34 (Ind. 2019).

166. Id. at 632 .

167. Id.

168. Id.

169. Id.

170. Id. at 633 .

171. Id.

172. Id. at 635 .

173. Id. at 634 (citing Thomson, 11 N.E.3d 982, 993 (Ind. Ct. App. 2014)). 
building" as a rental dwelling. ${ }^{174}$ The Court also found that the term "completed addition" is ambiguous because it does not have a single definition and reasonably intelligent people could differ as to its meaning. ${ }^{175}$ Because "insurance policies are to be construed strictly against the insurer," the Court construed the ambiguous term contained within the Policy against the Insured and held that the detached garage was covered under the Policy as a "completed addition.".

\section{LIENS AND FORECLOSURES}

\section{A. BloomBank v. United Fidelity Bank F.S.B.}

In BloomBank v. United Fidelity Bank F.S.B., ${ }^{177}$ the Court of Appeals considered whether the plaintiff pleaded sufficient facts to bring claims for constructive fraud and actual fraud in order to establish the validity of a release contained in a purchase agreement. Having found that the plaintiff pleaded sufficient facts to allege fraud, the Court of Appeals considered whether the plaintiff pleaded sufficient facts to allege breach of contract and unjust enrichment. ${ }^{178}$ This appeal is the result of BloomBank's third amended complaint, which was dismissed by the trial court for failure to state a claim. ${ }^{179}$

United Fidelity Bank F.S.B. ("UFB") agreed to loan $\$ 7,700,000$, secured by a mortgage, to Estridge Development Company, Inc., a third party. ${ }^{180}$ BloomBank and two other banks (collectively, the "Participant Lenders") agreed to supply $\$ 3,275,000$ of the $\$ 7,700,000$ in exchange for a partial interest in the profits and losses associated with the loan. ${ }^{181}$ This sale was subject to a Participation Agreement, which obligated UFB, among other things, to "promptly notify the Participant of events of which it has actual knowledge and which might materially adversely affect its interest." 182 Estridge eventually defaulted on the loan, and UFB filed a foreclosure action against Estridge. ${ }^{183}$ UFB then filed for a sheriff's sale of the collateral property, but a competing lien holder in the foreclosure action filed a notice of appeal (the "Anderson Appeal"). ${ }^{184}$ At the same time, UFB and the Participant Lenders were engaged in negotiations for UFB's repurchase of the Participant Lenders' interest in the loan. ${ }^{185}$ UFB offered

174. Id. at 635 .

175. Id.

176. Id. (citing Thomson, 11 N.E.3d at 993).

177. BloomBank v. United Fidelity Bank F.S.B., 113 N.E.3d 708 (Ind. Ct. App. 2018), transfer denied, 123 N.E.3d 129 (Ind. 2019).

178. Id. at $720-21$.

179. Id. at 717-18.

180. Id. at 713 .

181. Id.

182. Id. at 714 .

183. Id.

184. Id.

185. Id. 
to repurchase the Participant Lenders' interest for less than one-third of the original purchase price. ${ }^{186}$ UFB informed the Participant Lenders this lower price was, in part, due to the pending Anderson Appeal. At the sheriff's sale, UFB bought the collateral property for $\$ 2,800,000$, millions of dollars below its actual value. ${ }^{187}$

The Participant Lenders and UFB subsequently agreed to a repurchase price, and UFB bought the Participant Lenders' interest. ${ }^{188}$ This sale was subject to a Purchase Agreement which contained a release that prevented the Participant Lenders from suing UFB for anything arising out of or relating to the original loan or their participatory interests. ${ }^{189}$ Just thirty-seven days later, the Anderson Appeal settled and UFB transferred title to the collateral property to an affiliate, Village Capital, who began selling portions of the property amounting to over $\$ 9,500,000$ in gross proceeds. ${ }^{190}$

It was not until after BloomBank sold its participatory interest that it discovered UFB had actively discouraged one or more third parties from submitting bids at the sheriff's sale in excess of the judgment bid submitted by UFB. ${ }^{191}$ BloomBank also discovered that UFB had refused to entertain offers from one or more third parties interested in purchasing the Property outside of the sheriff's sale. ${ }^{192}$

1. Differing Standards of Review.-Because the Court of Appeals had to first address the allegations of fraud before it could address BloomBank's other claims, the court outlined two different standards of review and stated that it reviews "a Rule 12(B)(6) dismissal de novo... and accept[s] as true the facts alleged in the complaint, viewing the pleadings in the light most favorable to the nonmoving party, with 'every reasonable inference construed in the nonmovant's favor." 193 While the Court of Appeals acknowledged that Indiana typically only requires that pleadings contain a short and plain statement of the facts and a demand for relief, ${ }^{194}$ there is an exception to Indiana's liberal notice pleading requirements when a claim involves fraud. ${ }^{195}$ Generally, "to allege fraud sufficiently, the pleadings must state the time, the place, the substance of the false representations, the facts misrepresented, and identification of what was procured

186. Id

187. Id. at 715 .

188. Id.

189. Id. at 716 .

190. Id. at 717 .

191. Id.

192. Id.

193. Id. at 720 (quoting Birge v. Town of Linden, 57 N.E.3d 839, 843 (Ind. Ct. App. 2016)).

194. Id. (citing Trail v. Boys \& Girls Clubs of Nw. Ind., 845 N.E.2d 130, 135 and T.R. 8(A) (Ind. 2006)); see also Mizen v. State ex rel. Zoeller, 72 N.E.3d 458, 467 (Ind. Ct. App. 2017) (citation omitted) (noting Indiana's trial rules "are designed to avoid pleading traps and, to the greatest extent possible, ensure that cases are tried on the issues that their facts present").

195. Id. at 721 . 
by fraud." 196

2. Effect of the Release.-BloomBank alleged breach of contract and unjust enrichment; however, the Purchase Agreement contained a release barring BloomBank from suing UFB for any claim arising out of or related to the Participation Agreement or the loan. ${ }^{197}$ Still, the Court of Appeals found that if BloomBank pleaded sufficient facts to allege that UFB fraudulently induced BloomBank into signing the Purchase Agreement, then the release might not be binding and would not bar the breach of contract and unjust enrichment claims. ${ }^{198}$ Accordingly, the Court of Appeals first considered BloomBank's claims for constructive and actual fraud. ${ }^{19}$

3. Constructive Fraud.-The Court of Appeals identified the elements of constructive fraud as: "(i) a duty owed by the party to be charged to the complaining party due to their relationship; (ii) violation of that duty by the making of deceptive material misrepresentations of past or existing facts or remaining silent when a duty to speak exists; (iii) reliance thereon by the complaining party; (iv) injury to the complaining party as a proximate result thereof; and (v) the gaining of an advantage by the party to be charged at the expense of the complaining party." ${ }^{200}$ Further, "the existence of a duty may arise in two ways: (1) the existence of a fiduciary relationship and; (2) the case of a buyer and seller."201

Because a contract does not create a fiduciary relationship, the Court of Appeals found that BloomBank failed to state a claim for constructive fraud based on UFB's alleged fiduciary duty. ${ }^{202}$ But, it found that BloomBank did state a claim that UFB owed a duty as the buyer in a buyer-seller relationship. ${ }^{203}$ The Court of Appeals also found that BloomBank sufficiently alleged that UFB violated its duty to BloomBank by making deceptive material misrepresentations and remaining silent when it had a duty to speak, because BloomBank alleged that UFB falsely represented that inquiries into the property were only about portions of the property, not the whole property. ${ }^{204}$ BloomBank further pleaded sufficient facts alleging that UFB fraudulently induced it to enter into the Purchase Agreement by providing incomplete and misleading information about the Anderson Appeal. ${ }^{205}$ BloomBank sufficiently alleged that it relied on UFB's fraudulent representations and omissions and pleaded sufficient facts to show that it suffered injury in the amount of the difference between the full value of the

196. Id. (quoting Kapoor v. Dybwad, 49 N.E.3d 108, 120 (Ind. Ct. App. 2015)).

197. Id.

198. Id. at 721-22 (citing Tru-Cal, Inc. v. Conrad Kacsik Instrument Sys., 905 N.E.2d 40, 44 (Ind. Ct. App. 2009)).

199. Id. at 722 .

200. Id. (citing Kapoor, 49 N.E.3d at 124).

201. Id. (citing Harmon v. Fisher, 56 N.E.3d 95, 99-100 (Ind. Ct. App. 2016)).

202. Id..

203. Id. at 722-23.

204. Id. at 723 .

205. Id. 
Participatory Lenders' interest and the amount UFB paid for it. ${ }^{206}$ Finally, the Court of Appeals found that BloomBank pleaded sufficient facts to show that UFB gained an advantage at BloomBank's expense in that UFB obtained both the collateral property and participatory interest for less than full value. ${ }^{207}$

4. Actual Fraud.-The Court of Appeals identified the elements of actual fraud as (1) material misrepresentation of past or existing facts by the party to be charged (2) which was false, (3) which was made with knowledge or reckless ignorance of the falseness, (4) which was relied upon by the complaining party, and (5) which proximately caused the complaining party injury. ${ }^{208}$ For elements (1), (2), (4), and (5) the court referred to its reasoning for constructive fraud. ${ }^{209}$ The Court of Appeals found that BloomBank sufficiently alleged that UFB did in fact make false representations with knowledge or reckless ignorance of the falseness of the representations because it alleged that UFB's representative was at the sheriff's sale and actively and purposely discouraged others from bidding against UFB on the collateral property. ${ }^{210}$

5. Breach of Contract.- - To successfully bring a claim for breach of contract, a plaintiff must prove (1) the existence of a contract, (2) the defendant's breach of the contract, and (3) damages from the breach. ${ }^{211}$ BloomBank did not allege sufficient facts to support the claim for breach of section 4.2, which required UFB to "administer the Loan consistent with a lender's usual and customary practices." 212 However, BloomBank's allegations that UFB failed to uphold its contractual obligation to keep BloomBank informed were sufficient to allege a breach of contract. ${ }^{213}$ Given the more liberal standard for notice pleading, as compared to the pleading standard for fraud, the Court of Appeals held that because BloomBank gave specific examples of failures to disclose events that might have materially and adversely affected its interests, the trial court was wrong to dismiss BloomBank's claim for breach of contract, except as it pertains to UFB's alleged failure to administer the loan "consistent with a lender's usual and customary practices." 214

6. Unjust Enrichment.-To prevail on a claim of unjust enrichment, a claimant must establish that a measurable benefit has been conferred on the defendant under such circumstances that the defendant's retention of the benefit without payment would be unjust. ${ }^{215}$ The Court of Appeals recalled that it has allowed a plaintiff to recover against a defendant for unjust enrichment even

206. Id. at 724 .

207. Id.

208. Id. at 725 (citing Kapoor v. Dybwad, 49 N.E.3d 108, 121 (Ind. Ct. App. 2015)).

209. Id.

210. Id.

211. Id. at 725-26.

212. Id. at 726 .

213. Id. at 727 .

214. $I d$. at 726 .

215. Id. at 728 (quoting Zoeller v. East Chicago Second Century, Inc., 904 N.E.2d 213, 220 (Ind. 2009)). 
when it was a third party that conferred the benefit on the defendant and the defendant did not request the benefit from the plaintiff. ${ }^{216}$ Here, Bloombank alleged that the benefit conferred was Village Capital's profits from the sale of the property that UFB fraudulently obtained. ${ }^{217}$ These alleged facts were sufficient to plead a claim of unjust enrichment. ${ }^{218}$

7. Conclusion.--In sum, the Court of Appeals affirmed the trial court's ruling that BloomBank failed to state a claim for constructive fraud based on UFB's alleged fiduciary duty and for breach of contract with regards to UFB's alleged violation of the "usual and customary practices" provision. ${ }^{219}$ However, the court of appeals reversed the trial court order with respect to all other claims pleaded by BloomBank. Consequently, the case was remanded for further proceedings. ${ }^{220}$

\section{B. Stroud v. Stone}

In Stroud v. Stone, ${ }^{221}$ the Court of Appeals considered (1) when a debtor fails to pay a promissory note, when does the statute of limitations begin, (2) how does an optional acceleration clause impact the statute of limitations, and (3) what is a per se unreasonable amount of time to wait before invoking an optional acceleration clause. Stone (the "Creditor") received a promissory note (the "Promissory Note") from Stroud (the "Debtor") that required monthly payments beginning on June 1, 2003 and maturing on July 1, 2013. ${ }^{222}$ The terms of the Promissory Note included an optional acceleration clause providing that upon default, and thirty days after written notice, the entire principal balance shall become due. ${ }^{223}$ The Creditor received payments through May 2008 but none after. $^{224}$ The Creditor filed the complaint seeking repayment on February 23, $2016 .{ }^{225}$ The Debtor had raised the statute of limitations as an affirmative defense in the trial court. ${ }^{226}$ The Debtor argued that "the statute of limitations runs from the note's maturity date of July 1, 2013," while the Creditor argued that "the cause of action on the note accrued in June 2008 when the note fell into default." ${ }^{227}$ The trial court agreed with the Creditor. ${ }^{228}$ The Debtor appealed. ${ }^{229}$

216. Id. at 729 .

217. Id.

218. Id.

219. Id. at 730 .

220. Id.

221. Stroud v. Stone, 122 N.E.3d 825 (Ind. Ct. App. 2019). But see Blair v. EMC Mortg., LLC, 139 N.E.3d 705, 709 (Ind. 2020) (“disapprov[ing]” Stroud).

222. Id. at 826 .

223. Id. at 830 .

224. Id. at 826 .

225. Id. at 828 .

226. Id.

227. Id. at 829 .

228. Id.

229. Id. at 830 . 
The Court of Appeals reversed, finding that the statute of limitations had passed and the claim on the note was time-barred. ${ }^{230}$ The Court determined that action on a promissory note executed after August 31, 1982, must be commenced within six years of when the action accrues under Indiana Code $\S 34-11-2-9 .^{231}$ The Court determined that the rule differs when the note has an optional acceleration clause. ${ }^{232}$ The Court acknowledged that the general rule for notes with optional acceleration clauses is that "the statute of limitations does not begin to run immediately upon the debtor's default but only when the creditor exercises the option to accelerate the debt" by an affirmative act. ${ }^{233}$ Yet, the Court determined that waiting until after the statute of limitations has passed to invoke an acceleration clause is per se unreasonable and "cannot be given effect." 234 The Court held that because the Creditor waited six years after default - past the statute of limitations - before making a demand for payment, the Creditor waited a per se unreasonable amount of time before invoking the optional acceleration clause. ${ }^{235}$

\section{LOCAL GOVERNMENT MATTERS}

\section{A. City of Charlestown v. Charlestown Pleasant Ridge Neighborhood Ass'n Corp.}

In City of Charlestown v. Charlestown Pleasant Ridge Neighborhood Ass'n Corporation, ${ }^{236}$ the Court of Appeals reviewed the Indiana Unsafe Building Law ("UBL"), the Home Rule Act, and the City of Charlestown's Property Maintenance Code ("PMC"). ${ }^{237}$ Here, the Charlestown Pleasant Ridge Neighborhood Association Corporation (the "Homeowners") filed a motion for preliminary injunction against the City of Charlestown, Indiana (the "City"). The Homeowners alleged that the City's application of the PMC violated the UBL, the PMC itself, the Equal Protection Clause, and Indiana Constitution's Privileges and Immunities Clause. ${ }^{238}$ The trial court ruled that the City was not required to follow the UBL or the PMC strictly. The court also found that the Homeowners were unlikely to win the claim that the City's application of the PMC violated the UBL. The trial court, however, determined that the Homeowners were likely to

230. Id. at 831 .

231. Id. at 829 .

232. Id. at 830 (citing Smither v. Asset Acceptance, LLC, 919 N.E.2d 1153, 1160 (Ind. Ct. App. 2010)).

233. Id. at 831 (citing Collins Asset Group, LLC v. Alialy, 115 N.E.3d 1275, 1279 (Ind. Ct. App. 2018)).

234. Id. (citing Collins, 115 N.E.3d at 1279).

235. $I d$.

236. City of Charlestown v. Charlestown Pleasant Ridge Neighborhood Ass'n Corp., 111 N.E.3d 199 (Ind. Ct. App. 2018).

237. Id. at 200, 203.

238. Id. at 200 . 
show that the City's enforcement of the PMC violates the PMC itself, the Equal Protection Clause, and Indiana Constitution's Privileges and Immunities Clause. ${ }^{239}$ Thus, the trial court granted the Homeowner's motion for preliminary injunction on those three issues. The UBL defines an "unsafe building" or "unsafe premise" as a building or structure that is:

(1) in an impaired structural condition that makes it unsafe to a person or property; (2) a fire hazard; (3) a hazard to the public health; (4) a public nuisance; (5) dangerous to a person or property because of a violation of a statute or ordinance concerning building condition or maintenance; or (6) vacant or blighted and not maintained in a manner that would allow human habitation, occupancy, or use under the requirements of a statute or an ordinance. ${ }^{240}$

The UBL applies to consolidated cities, but the legislative body for a county or municipality can adopt the ordinance if it chooses to. ${ }^{241}$ Additionally, the UBL is permissive in that the enforcement authority may issue an order when a building is deemed unsafe; however, the enforcement authority must provide homeowners with notice of noncompliance before issuing a fine. The enforcement authority must also provide property owners with a "sufficient time" (ten to sixty days) to repair or rehabilitate an unsafe building. ${ }^{242}$ After the grace period, property owners are fined $\$ 2,500$ for non-compliance. ${ }^{243}$ An additional penalty is imposed, up to $\$ 1,000$ every ninety days after the initial grace period, for non-compliance under the UBL. ${ }^{244}$

The UBL does not, however, reference any specific safety standards. Because the UBL does not establish safety guidelines or standards, the City enacted the PMC pursuant to the powers granted from the Home Rule Act. ${ }^{245}$ The PMC established minimum public health and safety standards for residential and nonresidential structures and gave the City the power to inspect structures for safety compliance. ${ }^{246}$ Despite the procedural safeguards set forth in the UBL, the Homeowners were immediately fined when issued a noncompliance order and charged additional fees each passing day. ${ }^{247}$

The Home Rule Act provides the "policy of the state ... to grant units all the powers that they need for the effective operation of government as to local affairs." 248 Under the Home Rule Act, "[i]f there is a constitutional or statutory provision requiring a specific manner for exercising a power, a unit wanting to

239. Id. at 201.

240. Id. at 205; see also IND. CODE § 36-7-9-4 (2019).

241. Id.

242. Id. at 206.

243. Id.

244. $I d$.

245. Id.; see also IND. CODE $\S \S 36-7-9-3,4$ (2019).

246. Id. at 202.

247. Id. at 202-03.

248. Id. at 206 (quoting IND. CODE $\S 36-1-3-2$ (2019)). 
exercise the power must do so in that manner." ${ }^{249}$ Therefore, the Home Rule Act always applies. Because of the Home Rule Act, any city that adopts the UBL must abide by the UBL's procedural requirements.

The Court of Appeals concluded that the City is required to comply with the UBL and that the City must enforce the PMC within the scope of the UBL. ${ }^{250}$ By adopting the UBL through an ordinance in 2001, the City was required to comply with the procedural safeguard of the UBL. ${ }^{251}$ The Court of Appeals reasoned that the UBL applied if and when noncompliance orders were issued for safety violations. ${ }^{252}$ Therefore, the Court of Appeals remanded, instructing the trial court to ensure that the PMC "work within the confines and strictures of the UBL" and to reconsider the Homeowner's claims that the City's enforcement of the PMC violates the PMC itself. ${ }^{253}$

\section{B. City of New Albany v. Board of Commissioners of the County of Floyd}

In City of New Albany v. Board of Commissioners of the County of Floyd, ${ }^{254}$ the Court of Appeals interpreted and applied Indiana Code §36-9-13(a)(6), which outlines building authorities' ability to hold, use, or dispose of real or personal property. In 1992, the New Albany Floyd County Building Authority (the "Building Authority"), the City of New Albany (the "City"), and Floyd County (the "County") established an agreement, in which the County would lease property from the Building Authority for fifteen years and the City would sublease space on the property from the County. ${ }^{255}$ The 1992 lease also included a turn-over provision which provided:

[i]n the event [the County] has not exercised its option to purchase the [property] ... and has not exercised its option to renew this Lease. . the [property] shall become the absolute property of [the County], and, upon [the County's] request, [the Building Authority] shall execute proper instruments conveying to [the County] all of [the Building Authority's] title thereto. ${ }^{256}$

After the 1992 lease expired in September 2008, the City and the County

249. Id. at 207 (quoting IND. CODE $\S 36-1-3-6$ (2019)).

250. $I d$.

251. Id.

252. Id. at 206 ("[T] hese provisions of the UBL apply whenever the enforcement authority does choose to issue an order..." (emphasis added)).

253. Id. at 201.

254. City of New Albany v. Bd. of Comm'rs of the Cty. of Floyd, 125 N.E.3d 636 (Ind Ct. App. 2019), trans. granted, vacated, No. 19S-MI-674, 2019 WL 7176551 (Ind. Dec. 19, 2019). As of the date of publication of this Article, the Supreme Court affirmed the trial court's decision in 141 N.E.3d 1220 (Ind. 2020).

255. Id. at 638 .

256. Id. 
continued occupying the property and paying costs to the Building Authority. ${ }^{257}$ In 2018, the County requested the Building Authority transfer title of the property to the County pursuant to the turn-over provision, but the Building Authority declined. $^{258}$ The County then filed suit for declaratory judgment and specific performance. ${ }^{259}$ The court found in favor of the County. ${ }^{260}$

The Court of Appeals reversed and remanded, finding that the Building Authority lacked statutory authority to agree to the lease provision that allowed the county to demand the deed after completion of the lease term. ${ }^{261}$ Indiana Code $\S 36-9-13(a)(6)$ permits building authorities to "acquire real or personal property by gift, devise, or bequest and hold, use, or dispose of that property for the purposes authorized by this chapter ...." ${ }^{\prime 262}$ The Court specifically found that use of the word "that" in the statute refers only to property acquired by gift, devise, or bequest. ${ }^{263}$ Thus, because the property was not acquired by gift, devise, or bequest, the Building Authority lacked the statutory authority to agree to the turnover provision. ${ }^{264}$ However, the Court also concluded that as a holdover tenant, the County still has the option to acquire the property by exercising its purchase option pursuant to other terms in the 1992 lease. ${ }^{265}$

\section{Grdinich v. Plan Commission for Town of Hebron}

In Grdinich v. Plan Commission for Town of Hebron, ${ }^{266}$ the Court of Appeals considered (a) whether a pond located on a piece of residential real property was subject to injunction and removal, and (b) whether the existence of an underground drainage pipeline located on the property owner's property created a sufficient basis to support an inverse condemnation claim. Grdinich (the "Property Owner") received a building permit from the Town of Hebron (the "Town") to build a house in a residential district. ${ }^{267}$ The Property Owner built a house and made improvements to a pond located on the property. ${ }^{268}$ The Town's Municipal Code of Ordinances (the "Ordinance") prohibited ponds in the residential district unless they meet certain requirements. ${ }^{269}$ The Property Owner's pond did not meet those requirements. ${ }^{270}$ The Town sought a mandatory

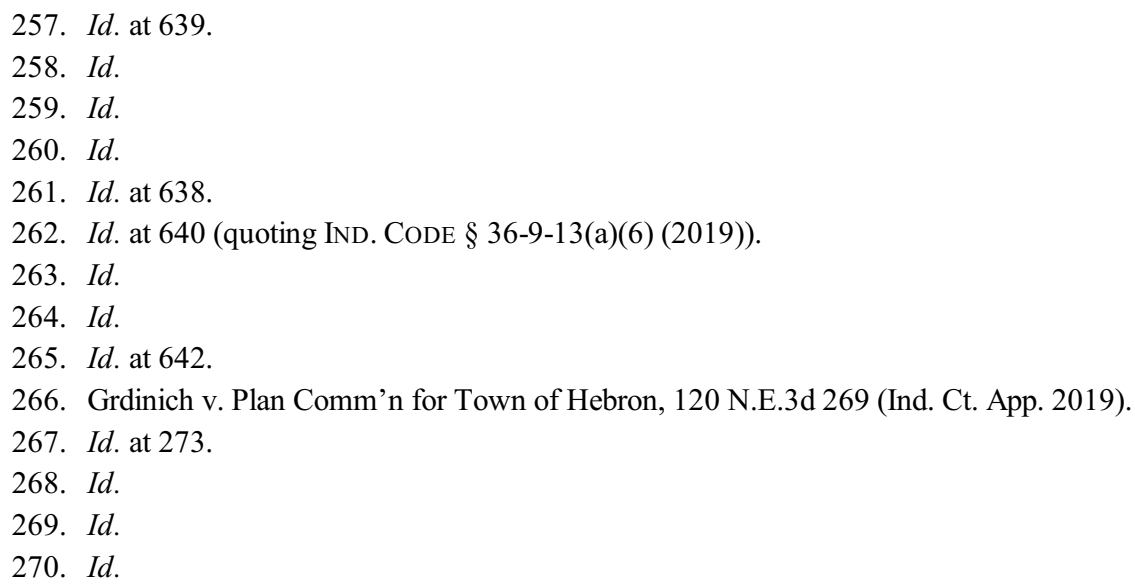


injunction against the Property Owner, asking the trial court to order him to remove the pond. ${ }^{271}$ The Property Owner filed a counterclaim against the Town arguing that he owned the pond and included a claim of inverse condemnation based on the existence of an underground drainage pipeline on the property. ${ }^{272}$ The Town moved to dismiss the Property Owner's counterclaim for failure to exhaust administrative remedies with the zoning board and failure to state claims upon which relief can be granted. ${ }^{273}$ The trial court granted the motion to dismiss. $^{274}$

The Court of Appeals affirmed in part, reversed in part, and remanded, holding that the trial court improperly dismissed the Property Owner's claims based on the pond, but that the inverse condemnation claim was properly dismissed. ${ }^{275}$

As an initial matter, the Court found that the Property Owner was entitled to a preliminary injunction before his claim should have been dismissed. ${ }^{276}$

Second, the Court found that the trial court improperly dismissed the Property Owner's promissory estoppel claim. ${ }^{277}$ At trial, the Property Owner argued that (a) he would not have constructed a home on the property if he had known that pond improvements would be prohibited, (b) the Town would not suffer any harm as a result of the injunction, (c) the pond remediated neighborhood drainage and mosquito problems, (d) neighbors supported the improvements, and (e) the pond was lawful because it was smaller than three acres and thus not subject to the Ordinance. ${ }^{278}$ On appeal, the Court reasoned that because the Property Owner's plans for improvements to the pond submitted to the Town were approved, the required permits were issued, and the Property Owner completed construction at significant time and expense in reasonable reliance on the Town's approval, the Property Owner relied on the approval to his detriment, and restoring the pond to its previous condition would cause drainage problems to the neighborhood and create potential public health concerns due to risk of insect infestation. ${ }^{279}$ Thus, the Court found that the trial court improperly dismissed the Property Owner's promissory estoppel claim. ${ }^{280}$

Finally, the Court affirmed the trial court by finding that the Property Owner's inverse condemnation claim was properly dismissed because the 150foot underground storm drainage pipeline was present when he purchased the property, nothing changed after his purchase, and he did not suffer any

271. Id.

272. Id. at $273-74$.

273. Id. at 274 .

274. Id.

275. Id. at 273 .

276. Id. at $278-79$.

277. Id. at 279 .

278. Id at $278-79$.

279. Id. at 279.

280. Id. 
damages. ${ }^{281}$

\section{PROPERTY TAXES AND TAX SALES}

\section{A. Kokomo Urban Development, LLC v. Heady}

In Kokomo Urban Development, LLC v. Heady, ${ }^{282}$ the Tax Court determined that the property tax cap should be applied to the assessed value of property without applying an economic revitalization area ("ERA") deduction. Kokomo Urban Development, LLC (the "Taxpayer") owned a property located in an ERA, which entitled the Taxpayer to a fifty-percent tax deduction in $2016 .{ }^{283} \mathrm{In}$ calculating the Taxpayer's maximum property tax liability for the 2016 tax year, the Howard County Auditor (the "Auditor") did not apply the ERA deduction to the gross assessed value of the property to calculate the property tax cap. ${ }^{284}$ The Auditor applied the ERA only for the purpose of calculating the Taxpayer's property taxes owed, deducting the required percentage from the gross assessed value of the property. The Taxpayer appealed the decision by the Indiana Board of Tax Review ("Indiana Board") to uphold the Auditor's calculation of the property tax cap and the ERA deduction. ${ }^{285}$

The issue on appeal was whether the ERA deduction should be applied to the assessed value of the property before calculating the property tax cap or only for the purpose of calculating the applicable tax liability. The Tax Court held that the ERA deduction was applicable only for determining tax liability, not for purposes of calculating the property tax cap, and affirmed the Indiana Board's decision. ${ }^{286}$ Gross assessed value is defined by Indiana statute as "the assessed value of property after the application of all exemptions under IC 6-1.1-10 or any other provision." 287 The Taxpayer argued that "exemptions" under the statute included "deductions." ${ }^{288}$ In rejecting that argument, the Tax Court reasoned that the Indiana legislature intended to exclude deductions from that provision because the Indiana tax code provides distinct definitions for "deductions" and "exemptions," and according to the principle of expressio unius est exclusio alterius, "the enumeration of certain things in a statute implies the exclusion of all others." 289 The Taxpayer alternatively argued that the phrase "any other provision" in the definition of "gross assessed value" meant "any other provision that reduces a property's gross assessed value" including deductions. ${ }^{290}$ The Tax

281. Id. at 280 .

282. Kokomo Urban Dev., LLC v. Heady, 125 N.E.3d 15 (Ind. T.C. 2019).

283. Id. at 16-17.

284. Id. at 17; see also IND. CODE § 6-1.1-20.6-7.5 (2019).

285. Kokomo Urban Dev., LLC, 125 N.E.3d at 17.

286. Id. at 20-21.

287. Id. at 18 (citing IND. CODE $\S 6-1.1-20.6-1.6$ (2016)).

288. Id.

289. Id. at 20 .

290. Id. (emphasis in original). 
Court rejected this argument and reasoned that words may not be read into the statute if not explicitly there, and that the grammatical structure of the statute did not support the Taxpayer's argument. ${ }^{291}$

Since the Tax Court determined that "exemptions" and "deductions" have distinct meanings, and the definition of "gross assessed value" does not mean "any other provision that reduces a property's gross assessed value," the Tax Court decided that the ERA deductions should not be applied in calculating the property tax cap and affirmed the Indiana Board's decision to uphold the Auditor's calculation of the Taxpayer's property tax liability.

\section{$B$. Wigwam Holdings LLC v. Madison County Assessor}

In Wigwam Holdings LLC v. Madison County Assessor, ${ }^{292}$ the Tax Court considered the validity of the Indiana Board of Tax Review's final determination, which upheld Wigwam Holdings LLC's (the "Owner") property assessment. The Owner acquired a parcel of land in a market transaction for $\$ 0$ with an agreement to restore the gymnasium on the property with an escrow of $\$ 630,000 .{ }^{293}$ For the 2015 tax year, the Madison County Assessor valued the parcel at $\$ 11,415,000$, and following an appeal, the Madison County Property Tax Assessment Board of Appeals reduced the assessed value to $\$ 2,115,200 .{ }^{294}$ Upon review at the Indiana Board Hearing, the Owner presented an appraisal that estimated the market value of the property at only $\$ 68,500$, because the property was "functionally and economically obsolete" due to physical deficiencies. ${ }^{295}$ The Indiana Board upheld the property assessment of $\$ 2,115,200$ and the Owner appealed. ${ }^{296}$

The Tax Court upheld the Indiana Board's final determination, finding that the Owner failed to make a prima facie case for reducing the Indiana Board's assessment. ${ }^{297}$ The Tax Court rejected the Owner's argument that the presentation of a USPAP-compliant proposal automatically establishes a prima facie case for reducing a property assessment. ${ }^{298}$ In Indiana, the current property assessment system measures a property's market value-in-use, which represents the value of the property "for its current use, as reflected by the utility received by the owner or by a similar user, from the property." 299 Further, the Tax Court established that when a property's current use is inconsistent with its highest and best use, the market value-in-use will not equal market value, therefore the Owner's appraisal

291. Id. at 20.

292. Wigwam Holdings LLC v. Madison Cty. Assessor, 125 N.E.3d 7 (Ind. T.C. 2019).

293. Id. at 9.

294. Id. at 10.

295. Id. at 9.

296. Id.

297. Id. at 10.

298. Id. at 12 .

299. Id. (citing IND. CODE $\S 6-1.1-31-6(c)$ (2015)). 
alone does not constitute probative evidence of the property's utility. ${ }^{300}$ Additionally, the Tax Court upheld the Indiana Board's finding that the seller - a governmental entity who sold the property for zero dollars with a $\$ 630,000$ escrow-was not typically motivated and therefore the sale was not a market transaction. ${ }^{301}$ Finally, the Tax Court rejected the Owner's claim that abnormal obsolescence diminished the value of its property because the Owner merely attacked the property assessment methodology and failed to affirmatively present evidence to identify causes of the purported obsolescence. ${ }^{302}$

\section{ZONING}

\section{A. Essroc Cement Corp. v. Clark County Board of Zoning Appeals}

In Essroc Cement Corp. v. Clark County Board of Zoning Appeals,${ }^{303}$ the Court of Appeals considered an appeal to the Clark County Board of Zoning's decision regarding a concrete manufacturer's ability to use liquid waste derived fuels ("LWDF") under Clark County's then-current zoning district. The manufacturing facility operated on land zoned M2 for Heavy Industrial Use. ${ }^{304}$ In 2014, the company requested a determination from the Clark County Plan Commission about the permissibility of burning LWDF at its facility. ${ }^{305}$ The Plan Commission initially responded in a letter indicating the burning of LWDF was permitted. ${ }^{306}$ However, the Plan Commission staff later issued a second letter, which revoked the first, and indicated that the company would need to obtain a variance or re-zone as M3, which is a Hazardous Waste Disposal District. ${ }^{307}$ The company appealed to the Clark County Board of Zoning Appeals (the "Board"). ${ }^{308}$ The Board held a public hearing and determined that the proposed use of LWDF is prohibited in an M2 zoning district, and the company would need to either re-zone to M3 or to petition for a use variance. ${ }^{309}$ The company then petitioned the trial court to review the decision of the Board, which ultimately resulted in this decision by the Court of Appeals.

The Court of Appeals, finding the Board's interpretations between M2 and M3 zoning correct, affirmed the trial court and the Board's decision. Because the company intended to receive, store, and burn LWDF as fuel for its machinery, and the Clark County Zoning Ordinance permits the storage, processing, and

300. Id.

301. Id. at 14 .

302. Id.

303. Essroc Cement Corp. v. Clark Cty. Bd. of Zoning Appeals, 122 N.E.3d 881 (Ind. Ct. App. 2019).

304. Id. at 884 .

305. Id.

306. Id.

307. Id.

308. Id.

309. Id. 
recycling of hazardous waste only in the M3 zoning district, the company's proposed use of LWDF is not permitted in the M2 zoning district as a primary or accessory use. ${ }^{310}$ The Court rejected the assertion that the burning of LWDF was allowed under the doctrine of accessory use, which recognizes that the right to establish and maintain a commercial or nonresidential use normally includes the right to add accessory uses that are secondary to the permitted one. Instead, the Court held to the principle of expressio unius est exclusio alterius-M3 specifically included the provisions about hazardous waste; therefore, that use is prohibited in an M2 zone. ${ }^{311}$ The first letter sent to the company was legally incorrect, and, therefore, the Plan Commission had the authority to revoke that letter and correct it with a new one without notice and hearing, just as the initial determination did not require notice and hearing.

\section{$B$. Pflugh v. Indianapolis Historic Preservation Commission}

In Pflugh v. Indianapolis Historic Preservation Commission, ${ }^{312}$ the Court of Appeals considered (1) whether David Pflugh (the "Adjacent Owner"), an adjoining property owner, had standing to obtain judicial review of a zoning decision, and (2) whether the Indianapolis Historic Preservation Commission (the "IHPC") and the Board of Zoning Appeals were entitled to an award of attorney's fees. ${ }^{313} 855$ North Street, LLC (the "Owner") petitioned the IHPC to rezone its property (the "Site") from SU-7 to D-8, to replace the vacant nursery school building with a mix of higher and lower density residential housing. ${ }^{314}$ The IHPC rezoned the entire Site to D-8, granted development standard variances, and issued a certificate of appropriateness (the "COA"). ${ }^{315}$ The variances permitted retail use and a reduction of the open space, the livability-space ratio, and the floor-area ratio. ${ }^{316}$ The Adjacent Owner lived directly across the street from the Site and he petitioned for judicial review of the grant of variances and the COA. ${ }^{317}$ The trial court concluded that the Adjacent Owner lacked standing to seek judicial review. ${ }^{318}$ The Adjacent Owner appealed. ${ }^{319}$

The Court of Appeals held that (1) the Adjacent Owner was not aggrieved as required to confer standing, and (2) the IHPC and the Board of Zoning appeals were not entitled to attorney's fees. ${ }^{320}$ To have standing, the Adjacent Owner must be "aggrieved" by the zoning decision, meaning that the petitioner must

\footnotetext{
310. Id. at 894-95.

311. Id. at 895 .

312. Pflugh v. Indianapolis Historic Pres. Comm'n, 108 N.E.3d 904 (Ind. Ct. App. 2018).

313. Id. at 906 .

314. Id.

315. Id. at 907.

316. Id. at 908 .

317. Id. at 906 .

318. Id. at 908 .

319. Id.

320. Id. at 910-11.
} 
experience a "substantial grievance, a denial of some personal or property right or the imposition . . . of a burden or obligation." ${ }^{321}$ Further, the Adjacent Owner must demonstrate an injury that is not "common to the community as a whole." 322 The Court rejected the argument that the Adjacent Owner's status as an adjoining property owner automatically rendered him aggrieved. ${ }^{323}$ The Adjacent Owner argued that the variances would create additional noise and traffic near his home. ${ }^{324}$ However, the Court held that the Adjacent Owner failed to show that the variances caused a special, individual injury to him. ${ }^{325}$ Finally, the Court ruled that the IHPC and the Board of Zoning Appeals were not entitled to attorney's fees because they failed to establish that the Adjacent Owner's contentions were utterly devoid of plausibility. ${ }^{326}$

\section{Town of Darmstadt v. CWK Investments-Hillsdale, LLC}

In Town of Darmstadt v. CWK Investments-Hillsdale, $L L C,{ }^{327}$ the Court of Appeals considered when the thirty-day appeal deadline begins to run on a board of zoning appeals determination. CWK Investments-Hillsdale, LLC, a developer, was initially denied an improvement location permit by the Evansville Area Plan Commission Site Review Committee and appealed to the EvansvilleVanderburgh County Board of Zoning Appeals ("BZA"). On June 15, the BZA held a hearing and orally reversed the denial. On September 5, the Town of Darmstadt (the "Town") sought judicial review of the BZA decision. ${ }^{328}$ The developer and BZA moved to dismiss the petition as untimely because the Town did not file the appeal within thirty days of the BZA's oral decision at the hearing as required under Indiana Code $\S 36-7-4-1605 .{ }^{329}$ The Town responded that the thirty-day requirement began when the BZA issued the written findings of fact it was required to file under Indiana Code $\S 36-7-4-915 .{ }^{330}$ The trial court agreed with the BZA and dismissed as untimely the Town's petition for judicial review. ${ }^{331}$

The Court of Appeals held that the oral determination made at the June 15 hearing constituted a zoning "decision" for the purposes of timing to file a

321. Id. at 908-09. (quoting Union Twp. Residents Ass'n, Inc. v. Whitley Cty. Redev. Comm'n, 536 N.E.2d 1044, 1045 (Ind. Ct. App. 1989)).

322. Id. at 910 .

323. Id.

324. Id. at 909.

325. Id. at 910 .

326. Id. at 911 .

327. Town of Darmstadt v. CWK Investments-Hillsdale, LLC, 114 N.E.3d 11 (Ind. Ct. App. 2018).

328. Id. at 12 .

329. Id. at 14-15; IND. CODE $\S 36-7-4-1016$.

330. Town of Darmstadt, 114 N.E.3d at 14.

331. Id. at 12 . 
petition for judicial review. ${ }^{332}$ The Court interpreted the plain language of the statute to mean that a board of zoning appeals must make its decision on a specific matter at the conclusion of the hearing, and this decision is not separate from the written findings of fact. ${ }^{333}$ The Court cited instructive decisions to support its reasoning that the written findings of fact are an explanation of a board's reasoning for a decision made at the hearing and not a distinct decision. ${ }^{334}$ Additionally, the Court reasoned that the statute does not provide an extension of time within which to file a petition beyond thirty days following the board's hearing decision. ${ }^{335}$ The statute also does not require that the board make findings of fact within thirty days of the hearing decision, and a petitioner is not required to submit findings of fact with the petition. ${ }^{336}$ Therefore, the Town was required to file its petition within thirty days of the BZA's hearing decision on June 15 .

Since the Town did not file its petition within thirty days of the BZA's decision made at the June 15 hearing, the Court of Appeals affirmed the trial court's decision to dismiss the petition as untimely. ${ }^{337}$

332. Id. at 17.

333. Id. at 14; see also IND. CODE § 36-7-4-919(e).

334. Town of Darmstadt, 114 N.E.3d at 15; see also Biggs v. Bd. of Zoning Appeals of City of Wabash, 448 N.E.2d 693, 694 (Ind. Ct. App. 1983) (holding that the board made its decision at the hearing because minutes "are not the event, but a record of the transpired event"); Hoagland v. Town of Clear Lake Bd. of Zoning Appeals, 871 N.E.2d 376 (Ind. Ct. App. 2007) (holding that even when a board fails to issue written findings of fact, a petitioner must file within thirty days of a hearing decision of which the petitioner is aware).

335. Town of Darmstadt, 114 N.E.3d at 17.

336. $I d$.

337. The dissent argued that the code defines a zoning decision as a final decision with nothing left to be accomplished, and therefore, the written findings of fact should constitute a zoning decision. Id. at 17-20. 